\title{
Do Tax Audit Increase Post-Audit Reported Income? Evidence from Indonesia
}

\author{
Andreas Prasetyo Nugroho ${ }^{1}$, Chaikal Nuryakin ${ }^{2}$ \\ ${ }^{1,2}$ Faculty of Economics and Business, Universitas Indonesia, Depok, Indonesia \\ andreas.prasetyon@gmail.com ${ }^{1}$
}

\begin{abstract}
A tax audit is a tool for tax authorities to verify the accuracy of taxpayers' income and deductions. This research aims to measure the impact selfimposed or voluntary tax audit on individual taxpayer reported income using difference-in-differences (DiD). We compared the annual taxpayers' reported income before and after-tax audit in 2012. The results show while the effect of a voluntary tax audit is negative for the lowest income bracket, it is significantly positive for the higher income bracket. Also, the effect of the tax audit on reported income for the top bracket is nine to seventeen times higher than for the lower income brackets. Thus, with limited audit resource, we recommend the government to push audit for the top income bracket.
\end{abstract}

Keywords: Behavioral Response, Impact Evaluation, Reporting Disclosure, Tax Audit.

\section{Introduction}

In recent years, taxation revenue is Indonesia's primary source of state income. This is shown by the data from the Financial Report of Central Government and State Budget, that for the latest three years (2015-2017) tax revenue contributed to around $75 \%$ of the total state income. Unfortunately, this is not followed by the increase of tax ratio (ratio of tax revenue and Gross Domestic Product). Based on World Bank data, Indonesia's tax ratio between 2014-2016 was struggling around $10 \%$. Consequently, major efforts are needed to raise unexplored and untouched sources of state income through tax compliance.

An effort by tax authority in Indonesia (Directorate General of Taxes/DGT) to determine compliance of taxpayers is conducting Tax Audit. Conducting Tax Audits is one of the many ways the government can testify taxpayer's compliance in fulfilling the obligation stated in General Tax Provisions and Procedures Law. Tax audit is a corrective way in Indonesia's taxation system applying the self-assessment system [1] The self-assessment system gives full trust to taxpayers to count, pay and report their tax compliance independently. Hence, taxpayers have full right and decision-making authority in fulfilling their tax compliance. The object of this research is taxpayers' response in stating/reporting their tax liability, particularly on the individual level, after having audited by the tax authority.

Self-assessment taxation system as described above surely has weaknesses. This system based on[2] is vulnerable to potency of under-reporting which is reporting income or turnover under the exact number. As Slemrod[2] said that rich people tend to avoid the tax (tax avoidance) and people in lower income tend to do tax evasion. Rich people tend to decrease their tax amount legally, meanwhile people in lower income tend to against law. This is related to the capability, cost and benefit from people in charge with. One of a kind of illegal things mostly done by taxpayer entire this state is tax evasion which defines as a decision to not reporting the whole profit and its effort to decrease tax payment (Sandmo, 2005). Taxpayer's 
decision to do tax evasion is affected by detected probability and punishment, number of penalty and level of individual risk aversion[2].

Tendency of tax evasion made the examination/audit function run by DGT clearer. Yet in fact, the number of audit done by DGT is too low seen from the number of Audit Coverage Ratio (ACR) data. Audit Coverage Ratio is the scope of tax audit counted from divide between audited taxpayers and number of taxpayers who have obligation to submit the Tax Return. ACR data for Individual Taxpayer in Indonesia for the latest three years described in Figure 1 below:

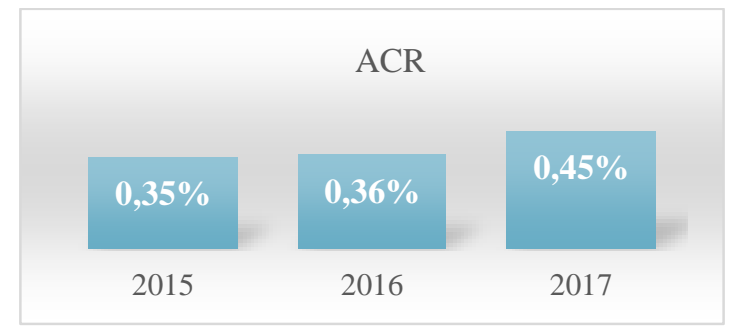

Fig. 1. Individual Taxpayer Audit Coverage Ratio years of 2015-2017.

The scope of tax audit for Individual Taxpayers remains under 1\% until 2017 making DGT reconsider further whether the implied audit has so far affected Taxpayers either implicitly or explicitly. Could the audit detect taxpayer attitude where they might report the tax compliance inappropriately? What is the impact of the tax audits done by DGT on taxpayer's attitude to be more compliant in the following period after the audit?

\section{Literature Review}

\subsection{Problem Conceptualization}

Economists explained that individual beings as economical agents tend to maximize their utility. However, this effort is constrained by limited resources (income). By this limitation, they have to use their highest capability/ purchasing power. Consequently, they tend to exert in maximizing the satisfaction based on the limited resources/budget [3].

Given the limited resources in terms of income gained by each person, the amount that will be reported also affects the decision of individual tax report/tax return. People tend to choose the optimal number to be reported even if they have to report under the actual income [4] underlined that the effect of a tax audit on the decision of reporting depends on audit probability and penalty/punishment from the authority. A person builds perception not only from the chance of being audited but also the probable condition when it does happen, in terms of probabilities of evasion and number of detected evasion. If an audit does not reveal tax evasion, the perception of the probability of being detected in the future becomes lower, decreasing the compliance of taxpayers themselves[5]. This is described by Gemmel and Ratto [5] as caused by taxpayers who have not formally received information related to the rules of audit implementation run by a tax authority, so taxpayers could not determine the actual number of audit probabilities. Furthermore, decisions in tax reporting and stating depend on taxpayers' perception in the time being audited and the number of unreported income which is intended to be concealed from an audit. Hence, based on Gemmel and Ratto[5] the experience of being audited changes taxpayers' future perception related to stating compliance report in the future. 


\subsection{Former Empirical Studies}

There are many discussions about tax evasion and audit probabilities. Many research used Allingham and Sandmo[4] as a reference. Allingham and Sandmo [4] state that tax reporting is a decision that is full of uncertainty faced by taxpayers because the tax authority does not automatically give a penalty to the taxpayers. The uncertainty in penalty results in two options for taxpayers to either report the exact number of income (comply) or report lower income than before, namely underreporting. Impact (pay off) for the taxpayer if they choose the latter depends on the probability of tax authority to either audit or not (probability of audit). If it is not audited, taxpayers will gain a bigger benefit than the first option (comply). In short, based on Allingham and Sandmo, the attitude of taxpayer compliance is affected by the chance/ probability of being audited by tax authority (audit probability) and the number of given penalty.

Based on Allingham and Sandmo's research elaborated above, it is scalable to some other tax evasion discussions particularly related to the tax audit run by the authority. Empirical studies are done to testify Allingham and Sandmo's portfolio which are mostly done in laboratory experimental studies. One of those studies was conducted by Spicer and Hero[6].Based on the result of Spicer and Hero [6] experiment done to their students, level of individual tax compliance is affected by the awareness of other people's experiences around them. Moreover, another factor affects results from the experience of being audited once. The experience of being audited significantly increases tax compliance. This is because in their study there was no social stigma which exists in society but could not be captured in laboratory experiments.

On the other hand, the effect of an audit to the compliance decision increases because of availability effect, where people tend to feel the probability of a certain event by recalling the former similar event in the past. In this case, the event of being audited is expected to cause the concern of increased probability of being audited again. The result of Spicer and Hero study is supported by that of Webley[7]. Conducted the study on his students, Webley [7] stated that increasing audit probability (probability of being audited) made people increase their income reporting more. With a slight difference done by Webley[7] in his study, the subject of the experiment is directed to make financial decisions related to the business they have built to fill the tax report accordingly in the future.

This study underlines the increase in audit probability due to the experience of being audited. The difference is that this study used real data from Indonesia's individual tax report which is more realistic than the laboratory experimental environment.

Another approach used to measure taxpayer response after an audit was done through an experimental study by Slemrod[8].Using taxpayer data in Minnesota, researchers gave treatments in the form of notifications about the upcoming audit for some randomly chosen taxpayers. The result of this study depended on how taxpayers understood or perceived the received notification letter of an audit. Overall results show that the treatment increases individual taxpayer income reporting, particularly those who are in the lower income group and middle class. However, it worked contradicting for individual taxpayers in the high-income level who decreased their income report instead. The decrease in income reporting, according to Slemrod[8], was probably because taxpayers in high-income groups have more complicated issues in taxation compared to the other income groups. Moreover, because of these complex tax affairs the high-income group individuals most probably use the help/assistance of tax consultants in tax reporting.

Another experimental study shows diverging results. As what has been done by Mittone[9] it shows that an individual tends to object after an audit. It is known as the bomb crater effect as in World War I when armies used bomb craters as a place to hide because they believed that 
a previously bombed area would not be bombed twice. This also happens in audits, and individuals tended to believe they will not be audited again after being audited once before so in the next report they will decrease their level of compliance/reporting. This was supported by experiments done by Maciejovsky[10] and Kastlunger[11]. Maciejovsky[10] proved the bomb crater effect to be true and stated that it is caused by two mechanisms namely misperception of chance and loss repair. Misperception of chance is an assumption that a random event might happen again sooner if it has not happened for some time. However, the event has less probability if it just happened recently.

Meanwhile, loss repair mechanism is a condition where people cover unpredicted former loss, in this case, is a penalty because of tax evasion. A way to cover up is by doing risky activities in the following period namely underreporting in income revelation in the tax reporting. Results from Maciejovsky[10] stated that misperception of the chance mechanism is a more dominant determinant affecting bomb crater effect.

On the other hand, there are a few studies about taxpayer response after tax audit using real data of tax returns. One of them is by DeBacker[12] confirmed that audit impacts the increasing of audited taxpayer's income reporting. Different amounts depend on the variety/source of income and individual characteristics.

Another study by Gemmel and Ratto[5] used tax return data related to the change of attitude as the impact of a tax audit. The study used data of individual taxpayers in the United Kingdom (UK). In their study, Gemmel and Ratto[5] intended to identify preventive effects from the tax audit whether taxpayers tend to be more compliant for the next years after experienced an audit. The results show compliant taxpayers (no penalty from audit result) tend to decrease their compliance after being audited. The contrary result occurred in non-compliant taxpayers (got a penalty from audit) which are more compliant after being audited. Another result from this study was the stronger response from business individual taxpayers rather than the personal taxpayer.

Another perspective is from Mendoza[13] where they used aggregate data from countries both some participants of OECD and some non-OECD. According to Mendoza[13] in the hypothesis, it stated that compliance will increase to a certain level of audit and decreases beyond that. Result of the study supported the hypothesis whereby the audit did not always gave a positive impact for taxpayers because they will reduce the compliance in the taxation obligation. However, in the case of using aggregate data from different countries, Mendoza [13] did not explain to what extent audit level affected individual tendency to turn the attitude less compliant after a certain level of an audit was reached.

Different results and different methods related to the impact of tax audit toward taxpayer compliance makes the topic into an interesting one o be inspected with different kinds of taxpayers in Indonesia. Former studies done abroad mostly used laboratory experiments to describe the response of taxpayer after tax audit. According to Andreoni[14], the experimental study has weaknesses primarily the setting of a less realistic experimental environment, so it does not exactly reflect real decision making. This study is intended to use a direct measurement from tax return data by taxpayers. Data in the form of direct measurement based on Andreoni[14] would be more reliable and reflect individual condition related to the investigated matter so it could resolve weaknesses of former studies which used experimental data. The use of direct measurement data to identify taxpayer responses after being audited has been rarely explored so far. Some studies have used direct measurement data from annual tax return but mostly was done in developed countries with a higher gross domestic product than Indonesia's and low social gaps such as in the United States, UK, Italy, and Denmark. In Indonesia, there has not yet been a study using direct measurement data (tax return data) related to individual taxpayer response toward an audit. 


\subsection{Hypotheses}

Based on theories and former empirical studies, the proposed hypotheses in this study tries to see whether there is an impact of experiencing an audit toward income reporting in taxpayer return. That is then compared with income reporting in a tax return from a taxpayer who never experienced a tax audit.

\section{Research Methodology}

\subsection{Source of Data}

Data used in this study is micro-data collected from the Directorate General Taxes that is individual tax return data (SPT WP OP). The data was used as a medium to explore individual taxpayers response within their reporting decision. Before using the tax return data, the authors identified the audited individual taxpayers from published notification to conduct a tax audit (Surat Perintah Pemeriksaan). The use of such data is to identify taxpayers samples listed in the treatment group. After accessing the audited taxpayers data, it is to be paired with the taxation reporting collected from annual tax return data.

Meanwhile, control group data only uses the taxation reporting data stated in the annual tax return. Sampling process of this study is described as follows: For analysis in this study, the authors used individual annual tax return data collected from DGT between 2009 to 2014. These data are sourced from the information recording system in DGT. According to DGT, data from this system after the year 2008 are accountable and valid. Based on this statement, this study chose to use data from the year 2009.

The data is divided into two groups namely treatment and control. For the treatment group, data was sourced from individual taxpayers who experienced a tax audit in 2012. Individuals in this group were listed from the notification to conduct a tax audit which was done in 2012. From audited taxpayer, the authors then traced the annual tax return reporting data between 2009 to 2014. Some extreme observations were excluded from the data. Beside the most extreme, tax return reporting data which happened before or after the treatment application were also excluded. For tax return reporting data listed in this treatment group, around 15 thousand tax returns were sourced as a sum between 2009 to 2014 .

Meanwhile, the control group in this study was formed from a separate audited individual taxpayer tax return data and non-audited individual taxpayer. The formation of the control group was taken from individuals had non-audited tax at all between 2009 to 2014. After accessing the non-audited tax return data, outliers on the data sample were excluded. As it was in the treatment group, data appearing only once before or after treatment application were excluded from this sampling as well. The objective was to end up with balanced data to form a data panel. Number of data for this control group came out to be around 2.88 million tax returns from the tax year of $2009-2014$.

Samples used in this study were individual tax return reporting data from DGT after considering characteristics of the taxpayer's district/domicile representation. It was intended to represent the entirety of Indonesia from many regions. This sample chosen was randomly done considering things above (stratified random) and being suited to DGT authorized data.

This study used the difference-in-difference method, so it needed a base year (baseline) which was used as the time differ variable. The year chosen as the baseline or treatment is 2012 because of the limited data from data source, DGT. Individual tax return data derived from DGT were from 2009-2014. Thus, 2012 was chosen as the baseline to get the same range of time between before and after treatments ( 3 years in each). Hence, taxpayers listed in the treatment group were those who experienced tax audits in the year 2012. Furthermore, for the tax year of 2011 reported in 2012, authors used the assumption that taxpayers reported the tax return within 
a maximum three months after the end of the year (2011). An audit which was done in 2012 was started and finished around March (after the 2011 tax return period is finished) so for the tax year of 2011 listed for the period before having an audit and for the year of 2012 listed to the year of after being audited.

\subsection{Empirical Specification}

As the authors have stated above, the objective of this study is to identify individual taxpayers responses as they change in the annual tax return. The change of attitude was compared between the audited taxpayers and non-audited ones. In other words, this study measures whether the applied policy by the regulator (DGT) has any impact of attitude change onto the individual taxpayer. According to Gertler et al. (2011), one of the methods used to evaluate policy impact was the difference-in-differences method. This method, based on Gertler et al. (2011) was used as a tool of policy impact comparing the results which are changes between the treatment and control group.

This study used difference-in-differences method in its regression analysis. The empirical specification in this study was suited to the model that Gemmel and Ratto[5] and DeBacker[12] used as follows:

$$
\gamma_{i t}=\underset{\beta_{6} \text { Regional }+\varepsilon_{i t}}{\beta_{1}+\beta_{1} d u m m y T}+\beta_{2} d u m m y G+\beta_{3} T G+\beta_{4} U \text { sia_daft }+\beta_{5} U_{\text {sia_daft }}{ }^{2}+
$$

with:

$\gamma \quad=$ reported income in annual Tax Return,

dummyT = dummy time (year) treatment,

dummyG = dummy treated group,

TG = interaction between dummyT and dummyG,

Usia_daft = length of time the taxpayer has been registered (in year),

Usia_daft ${ }^{2} \quad=$ squared length of time taxpayer has been registered,

Regional = dummy region/ location of taxpayer is registered.

The notation, $i$ in the equation above represents individual/ taxpayer, $t$ represents tax year, $\beta_{0}$ represents constant intercept of estimated parameter, $\beta_{1}$ to $\beta_{6}$ represent slope from the estimated parameter, while $\varepsilon_{i t}$ represents error term. Regional which is the dummy state/ location where the taxpayer is listed is categorized into 7, according to island group or province. DKI Jakarta was excluded from Java Island and turned into the baseline in this dummy regional. This is because DKI Jakarta is the center of the Indonesian and had the largest sample number in this sampling compared to other territories. Grouping of this dummy regional and region province is based on the paper in Appendix A.

Because the sample data combines both observations of individual and period of times, so the estimation of this research was done using panel data. However, because of the number of observation for each individual was different, it is called an unbalanced panel. Ekananda[15] stated that using panel data could consider the individual heterogeneity and control in each individual. Because of the use of dummy regional in this research, the applied approach in this research was the fixed effect model. Fixed effect model uses constants as a regressive parameter (intercept). 


\section{Findings}

\subsection{Statistic Descriptive Data}

The number of observation in this sample was 2.895.055 taxpayer return data from 2009 until 2014. The audited taxpayer observations were 15.030 tax returns, and the non-audited tax return were 2.880 .025 with the following details:

Table 1. Numbers of taxpayer's tax return in every taxpayer's treatment group.

\begin{tabular}{|l|l|l|}
\hline Tax Year & $\begin{array}{l}\text { Audited } \\
\text { Taxpayer }\end{array}$ & $\begin{array}{l}\text { Unaudited } \\
\text { Taxpayer }\end{array}$ \\
\hline 2009 & 2.127 & 396.074 \\
\hline 2010 & 2.807 & 462.853 \\
\hline 2011 & 2.708 & 452.043 \\
\hline 2012 & 2.468 & 513.284 \\
\hline 2013 & 2.554 & 543.738 \\
\hline 2014 & 2.366 & 512.033 \\
\hline Total & $\mathbf{1 5 . 0 3 0}$ & $\mathbf{2 . 8 8 0 . 0 2 5}$ \\
\hline
\end{tabular}

Meanwhile, the classification of the data based on the location of the registered taxpayer can be seen in table 2 below. These regions were classified according to the group of regional dummy variable that has been explained in the previous section. The table shows the range of samples over the region although still dominated by DKI Jakarta and Java Island.

Table 2: Data statistic based on the region.

\begin{tabular}{|l|r|r|r|r|}
\hline \multirow{2}{*}{ Region } & \multicolumn{2}{|c|}{ Unaudited } & \multicolumn{2}{c|}{ Audited } \\
\cline { 2 - 5 } & Amount & $\begin{array}{l}\text { Perce } \\
\text { ntage }\end{array}$ & Amount & $\begin{array}{l}\text { Perce } \\
\text { ntage }\end{array}$ \\
\hline $\begin{array}{l}\text { DKI } \\
\text { Jakarta }\end{array}$ & 723.397 & 25,12 & 2.945 & 19,59 \\
\hline $\begin{array}{l}\text { Java and } \\
\text { Madura }\end{array}$ & 1.188 .603 & 41,27 & 8.089 & 53,82 \\
\hline $\begin{array}{l}\text { Sumatera, } \\
\text { Riau }\end{array}$ & 473.513 & 16,44 & 1,432 & 9,53 \\
$\begin{array}{l}\text { Islands, } \\
\text { and }\end{array}$ & & & & \\
$\begin{array}{l}\text { Bangka } \\
\text { Belitung }\end{array}$ & 162.756 & 5,65 & 860 & 5,72 \\
\hline Borneo & 103.113 & 3,58 & 366 & 2,44 \\
\hline Sulawesi & 164.547 & 5,71 & 1,109 & 7,38 \\
\hline $\begin{array}{l}\text { Bali and } \\
\text { Nusa } \\
\text { Tenggara }\end{array}$ & & & & \\
\hline $\begin{array}{l}\text { Papua and } \\
\text { Maluku }\end{array}$ & 64.096 & 2,23 & 229 & 1,52 \\
\hline Total & 2.880 .025 & 100 & 15.030 & 100 \\
\hline
\end{tabular}

Furthermore, the descriptive statistics of the variables in this research is are seen in table 3. This table adds three variables, not included in the dummy variables. 
Table 3: Statistic descriptive of the variable.

\begin{tabular}{|l|l|l|l|l|}
\hline Variable & Obs & Mean & Min & Max \\
\hline $\begin{array}{l}\text { reported } \\
\text { income }\end{array}$ & 2.895 .055 & $\begin{array}{l}155,4 \\
\text { million }\end{array}$ & $\begin{array}{l}-4,85 \\
\text { billion }\end{array}$ & $\begin{array}{l}485,2 \\
\text { billion }\end{array}$ \\
\hline umur_daftar $^{2}$ & 2.895 .055 & 11,53 & 1 & 38 \\
\hline umur_daftar $^{2}$ & 2.895 .055 & 206,5 & 1 & 1444 \\
\hline
\end{tabular}

From table 3, we can see that the mean in reported income is 155,4 million rupiahs. Whereas, the lowest in the reported income observation is $-4,85$ billion rupiahs and the maximum is 485 billion. The mean of taxpayer age is 11,5-year-old. The lowest number is one year, and the highest is 38 years.

\subsection{Estimation Result}

Based on the estimation results using Fixed Effect model in Table 4 is seen that there is a significant difference in result for difference-in-differences estimator (TG) where no explanatory variable was given and after the explanatory variable/control variable was given. The significance of result for difference-in-differences estimator in that without explanatory variable had a $10 \%$ significance level and became more significant at the $1 \%$ level when the explanatory variable was given in its estimated equation.

Coefficient value for difference-in-differences estimator in this research is also different in that without any explanatory variable or after given the explanatory variable treatment which is the characteristic of the taxpayer in the reporting data of individual tax return. The estimated differences value of this examination was significant at the $10 \%$ level with the value of about 9,9 million rupiahs when there are no explanatory variables such as age and region of the taxpayer that has been used. But, when considering the registered age (usia_daft), squared registered age (usia_daft ${ }^{2}$ ), and the dummy of the taxpayer's domicile area, then the value increased towards 34-35 million (in rupiah) with $1 \%$ significance level.

The positive influence that exists in the form of the increase in income reporting after this auditing is by the previous empirical research that has been done by De Backer[12] and D'Agosto et al. (2018). Both of them stated that doing the inspection/audit had a significant effect to the increase in reporting of further disclosure of tax liability seen through the increase in reporting of taxable income[12] or the increase in reported earnings base.

Meanwhile, there were slightly different results shown by Gemmel and Ratto[5]. In that empirical study, they stated that there were two effects of the tax audit depending on the taxpayer's status or condition that have been audited. If the audited taxpayer was assumed as compliant (without any accrued tax assessments), then the tax liability disclosure will tend to be lower than before. It is inversely true with the taxpayer who is assumed as non-compliant according to the previous inspection; then they will revise the tax liability disclosure in the next period. However, this research did not explore as far as measuring the taxpayer's audit result because of data limitation, and the validity level was inferior to the existing data. This different result may be caused by the use of the variable of audit result finding where the group of audited taxpayers was separated into two; compliant and non-compliant besides considering the experience of having been audited as so in Gemmel and Ratto's[5] research. Whereas, this research only considered the experience of having been audited as the proxy to improve the taxpayer's understanding of the probability of getting audited. 
Table 4: The Estimation Result of Fixed Effect Model

\begin{tabular}{|c|c|c|c|c|}
\hline & \multicolumn{4}{|c|}{ Dependence Variable : reported income (in million rupiah) } \\
\hline & Estimation (1) & Estimation (2) & Estimation (3) & $\begin{array}{l}\text { Estimation } \\
\text { (4) }\end{array}$ \\
\hline dummyT $(\mathrm{dT})$ & $\begin{array}{l}35.75582 * * * \\
(1.56535)\end{array}$ & $\begin{array}{l}10.77963 \text { *** } \\
(2.70033)\end{array}$ & $\begin{array}{l}\text { 10.34320**** } \\
(2.70611)\end{array}$ & $\begin{array}{l}10.42029 * * * \\
(2.70495)\end{array}$ \\
\hline TG & $\begin{array}{l}9.87049 * \\
(5.37382)\end{array}$ & $\begin{array}{l}34.84668 * * * \\
(5.80685)\end{array}$ & $\begin{array}{l}35.28312 * * * \\
(5.80954)\end{array}$ & $\begin{array}{l}35.20602 * * * \\
(5.80900)\end{array}$ \\
\hline Usia_daft & & $\begin{array}{l}8.55453 * * * \\
(0.96151)\end{array}$ & $\begin{array}{l}15.93449 * * * \\
(1.35725)\end{array}$ & $\begin{array}{l}15.90880 * * * \\
(1.35730)\end{array}$ \\
\hline Usia_daft ${ }^{2}$ & & & $\begin{array}{l}-0.29524 * * * \\
(0.02355)\end{array}$ & $\begin{array}{l}-0.29522 * * * \\
(0.02355)\end{array}$ \\
\hline Regional.1 & & & & $\begin{array}{l}-303.45838^{*} \\
(173.69697)\end{array}$ \\
\hline Regional.2 & & & & $\begin{array}{l}-319.62049 \\
(197.86104)\end{array}$ \\
\hline Regional.3 & & & & $\begin{array}{l}-240.68327^{*} \\
(137.90983)\end{array}$ \\
\hline Regional.4 & & & & $\begin{array}{l}-202.49523 * \\
(117.89531)\end{array}$ \\
\hline Regional.5 & & & & $\begin{array}{l}-209.01367 \\
(138.61915)\end{array}$ \\
\hline Regional.6 & & & & $\begin{array}{l}-63.39843 \\
(123.54140)\end{array}$ \\
\hline Constants & $\begin{array}{l}135.94166^{* * * *} \\
(0.84849)\end{array}$ & $\begin{array}{l}50.80520 * * * \\
(9.89463)\end{array}$ & $\begin{array}{l}26.88561 * * \\
(11.04533) \\
\end{array}$ & $\begin{array}{l}239.21640 * * \\
(121.59949)\end{array}$ \\
\hline $\mathrm{N}$ & $2,895,055$ & $2,895,055$ & $2,895,055$ & $2,895,055$ \\
\hline R Square & 0.00024 & 0.00028 & 0.00033 & 0.00034 \\
\hline
\end{tabular}

The regression result for the explanatory variable considers that taxpayer's age factor (in this term registered age) positively affecting the tax liability disclosure. But for the square age variable (usia_daft ${ }^{2}$ ), it showed the negative result in their income reporting. These opposite results imply that taxpayer's registered age will have a positive impact in their tax report until a certain point or certain age and as they grow older they will attempt to decrease their income reporting even more. It is in line with [16]Supriyadi findings.

The next dummy was the taxpayer's regional/registered area based on their province. From 34 provinces, then classified into 7 regional with DKI Jakarta as its reference base (0 value). It can be seen that all of the area will have less value than DKI Jakarta because the value of that region was used as the base reference for the others. Even if there was any regional group which only half of them have significant value, and the other half were not. The significant regional group was group 1 (Java Islands except for the Special Capital Region of Jakarta), group 3 (the province in Borneo Islands), and group 4 (the province in Sulawesi Islands). This can show the 
fact that in Indonesia, the highest tax contributor until now is still dominated by taxpayers in Jakarta Province.

Based on the existing data structure, this research explores the response after the audit for each income group. This is to see which income group is the most responsive or less responsive to tax audit actions carried out by the tax authorities.

The classification of income groups is based on that of the Income Tax Law with a slight change to the income layer above 500 millions. Income groups above 500 millions are limited to the value of 10 billion rupiahs because from the sample in the treatment group, the maximum value of income from the existing observations only go up to five billion rupiahs. Thus, the income layer can be grouped into four groups as follows:

1 Reported income group from 0 to 50 million rupiahs;

2 Reported income group above 50 million rupiahs up to 250 million rupiahs;

3 Reported income group above 250 million rupiahs to 500 million rupiahs; and

4 Reported income group above 500 million rupiahs up to 10 billion rupiahs.

The estimation results for each income group are presented in Table 5 below. From the estimation results above, it can be seen that the response to audit/audit actions differs for each income group. We can see the response of each group from the coefficients in the TG variable. The results above show that the three groups, which are the second to fourth groups show a similar response: an increase in their reporting income after the examination/audit. But the magnitude of the increase is different with the increasing amount of income. For group 2 (the middle-income group) in this study, there is an increase in reporting income of around 21 million rupiahs for taxpayers who are audited compared to taxpayers who have not experienced an audit.

Similar results also occur in groups 3 and 4. Group 3 (the high-income group) responds to the audit action by the DGT by increasing the disclosure of income of approximately 44 million rupiahs for taxpayers who experienced an audit compared WP who does not experience an audit. Greater results are shown by group 4 (the very high-income group) which responds to the audit action by increasing disclosure of income by 331 million rupiahs. The amount of this income increase is likely to depend on the income group. From the above, it can be shown that middle to high-income groups tends to respond positively after this audit action. This result is by the availability effect revealed by Spicer and Hero[6].

Different responses are shown by group 1 (low-income group). Group 1 responds to the audit action by decreasing the disclosure of income by around 7 million rupiah. This shows that for taxpayers who are audited in the low-income group, after experiencing an audit will tend to reduce the disclosure of the report.

Estimation results based on income groups that have been described above for the characteristics of taxpayers in Indonesia show the opposite result when compared to previous studies. In the study Slemrod[8]. revealed that based on experimental results, an increase in the probability of audit would increase disclosure of reported income, especially for taxpayers with low and middle income groups. Taxpayers with high income tend to express lower income than before based on the perception that the audit will not automatically know and give punishment for tax evasion[8]

The results of this study also contradict the research of DeBacker[12]. They stated that based on taxpayer return data, taxpayers who are in the lowest income group (first quartile) respond the most among other income groups after experiencing an audit in terms of disclosure from their taxable income. And the opposite result happens for the highest income group. This result according to DeBacker[12] is likely because low-income groups may no longer have other sources of income that can be hidden so that they finally reveal the actual income after being audited. This is in contrast to high-income groups that may have multiple income sources so 
that they still have the possibility of hiding the income and report only a small part of the reality[12]

While the opposite results happen when using Indonesian taxpayers data, one of the reasons for this is probably due to a lot of overpayments audit made by DGT for low income group. This group (low income group) might still do not understand that when they declare overpayment they will be audited. So that after they have been audited, this low income group is likely to respond for the following year, one of which is by lowering their income reporting and hiding their tax credit so that they do not report overpayment and will not be audited. This different response from taxpayers in Indonesia can be used as a study for further research.

Table 5. The Estimation Result Based on Income Group

\begin{tabular}{|c|c|c|c|c|}
\hline Variable & $\begin{array}{c}\text { reported income } \\
\text { (in million) } \\
\text { Group 1 }\end{array}$ & $\begin{array}{c}\text { reported income } \\
\text { (in million) } \\
\text { Group 2 }\end{array}$ & $\begin{array}{c}\text { reported } \\
\text { income } \\
\text { (in million) } \\
\text { Group } 3\end{array}$ & $\begin{array}{c}\text { reported income } \\
\text { (in million) } \\
\text { Group } 4\end{array}$ \\
\hline $\begin{array}{c}\text { dummyT } \\
\text { (dT) }\end{array}$ & $\begin{array}{c}6.58849 * * * \\
(0.03693)\end{array}$ & $\begin{array}{c}-0.85169 * * * \\
(0.07376)\end{array}$ & $\begin{array}{l}-0.26801 \\
(0.43241)\end{array}$ & $\begin{array}{c}0.33620 \\
(5.55138)\end{array}$ \\
\hline TG & $\begin{array}{c}-7.07111 * * * \\
(0.39271)\end{array}$ & $\begin{array}{c}20.90597 * * * \\
(1.32358)\end{array}$ & $\begin{array}{c}44.34166 * * * \\
(5.34032)\end{array}$ & $\begin{array}{c}331.33462 * * * \\
(77.47091)\end{array}$ \\
\hline Usia_daft & $\begin{array}{c}-1.74446 * * * \\
(0.01980)\end{array}$ & $\begin{array}{c}13.17008 \text { *** } \\
(0.04083)\end{array}$ & $\begin{array}{c}31.24009 * * * \\
(0.25826)\end{array}$ & $\begin{array}{c}160.02077 * * * \\
(3.43626)\end{array}$ \\
\hline Usia_daft $^{2}$ & $\begin{array}{c}-0.06234 * * * \\
(0.00047)\end{array}$ & $\begin{array}{c}-0.18932 * * * \\
(0.00132)\end{array}$ & $\begin{array}{c}-0.31448 * * * \\
(0.00876)\end{array}$ & $\begin{array}{c}-0.44628 * * * \\
(0.12272)\end{array}$ \\
\hline Regional.1 & $\begin{array}{c}-2.94146 \\
(12.20510)\end{array}$ & $\begin{array}{l}86.68933 * \\
(45.09391)\end{array}$ & - & - \\
\hline Regional.2 & $\begin{array}{c}-4.43210 \\
(13.43532) \\
\end{array}$ & $\begin{array}{c}112.62432 * * \\
(50.71805) \\
\end{array}$ & - & - \\
\hline Regional.3 & $\begin{array}{c}10.34935 \\
(11.80502)\end{array}$ & $\begin{array}{c}89.92407 \\
(58.28262)\end{array}$ & - & - \\
\hline Regional.4 & $\begin{array}{l}-19.96234 \\
(13.95107)\end{array}$ & $\begin{array}{l}-55.25250 \\
(53.05624)\end{array}$ & - & - \\
\hline Regional.5 & $\begin{array}{c}-2.81186 \\
(12.72834) \\
\end{array}$ & $\begin{array}{l}135.37715^{*} \\
(74.96158) \\
\end{array}$ & - & - \\
\hline Regional.6 & - & $\begin{array}{l}93.71173 * * \\
(46.09998)\end{array}$ & - & - \\
\hline Constant & $\begin{array}{c}57.79900 * * * \\
(8.88612) \\
\end{array}$ & $\begin{array}{c}-64.84776 * * \\
(29.01532) \\
\end{array}$ & $\begin{array}{c}61.17624 * * * \\
(1.77338)\end{array}$ & $\begin{array}{c}-509.87838 * * * \\
(23.68670) \\
\end{array}$ \\
\hline $\mathrm{N}$ & $1,229,913$ & $1,324,139$ & 200,380 & 135,360 \\
\hline R-squared & 0.12173 & 0.29784 & 0.37926 & 0.16572 \\
\hline
\end{tabular}




\section{Conclusions}

This research aims to see the different responses of individual's behavior after having been audited by using individual tax return as the micro data. This response was measured from the behavior of their income disclosure from audited taxpayers in the annual tax return compared to the income disclosure in unaudited taxpayers. From the measurement result by using the difference-in-differences method, it is revealed that the audited taxpayers tend to have higher income disclosure in their annual report of tax return than the unaudited taxpayers at all. With the higher disclosure values in their tax report, the audited taxpayers were relatively more compliant in disclosing their income than the unaudited ones.

This research aims to depict the significance of the audit by tax authority and the effect on the taxpayer's behavior. Therefore, with the lack of Directorate General of Taxes as the tax authority, it can improve either the audit's quality or quantity to have positive effects directly and indirectly to the taxpayer. The lack of DGT was the number of auditors and cost of audit either in terms of inspection or the payroll for the tax auditors (budget constraint). This can be taken into policy consideration as well as for the audit plan and strategy that will be conducted by Directorate General of Taxes to the individual tax return. This research also expected to give academic contribution in the form of empirical prove related to how the consideration of taxpayer's behavior which audited and unaudited especially in the developing country. With method and another data resource, an academic debate toward the taxpayer's response after have been audited or the increase in audit probability still can be explored.

\section{References}

[1] T. Suparto, "Pengaruh Pemeriksaan Pajak terhadap Kepatuhan Wajib Pajak .” 2007.

[2] J. Slemrod, "Cheating Ourselves: The Economics of Tax Evasion," J. Econ. Perspect., vol. 21, no. 1, p. 48, 2007.

[3] W. Nicholson and C. Snyder, Microeconomic Theory:Basic Principles and Extensions. Ohio: South-Western Cengage Learning, 2012.

[4] M. G. Allingham and A. Sandmo, "Income Tax Evasion: A Theoretical Analysis," J. Public Econ., vol. 1, no. 3, p. , 1972.

[5] N. Gemmel and M. Ratto, "Behavioral Responses to Taxpayer Audits: Evidence from Random Taxpayer Inquiries," Natl. Tax J., vol. 65, no. 1, p. , 2012.

[6] M. W. Spicer and R. E. Hero, "Tax Evasion and," Heuristics. J. Public Econ., vol. 26, no. 263, p. , 1985.

[7] P. Webley, "Audit Probabilities and Tax Evasion in a Business Simulation," Econ. Lett., vol. 25, no. 267, p. 270, 1987.

[8] J. Slemrod, M. Blumenthal, and C. Christian, "Taxpayer response to an increased probability of audit: evidence from a controlled experiment in Minnesota." 2001.

[9] L. Mittone, "Dynamic Behaviour in Tax Evasion:An Experimental Approach," J. Socio. Econ., vol. 35, no. 813, p. , 2006.

[10] B. Maciejovsky, E. Kirchler, and H. Schwarzenberger, "Misperception of chance and loss repair: On the dynamics of tax compliance," J. Econ. Psychol., vol. 28, no. 678, p. 691, 2007.

[11] B. Kastlunger, E. Kirchler, L. Mittone, and J. Pitters, "Sequences of Audits, Tax Compliance, and Taxpaying Strategies," J. Econ. Psychol., vol. 30, no. 405, p. 418, 2009.

[12] J. DeBacker, B. T. Heim, A. Tran, and A. Yuskavage, "Once Bitten, Twice Shy? The Lasting Impact of IRS Audits on Individual Tax Reporting," J. financ. econ., vol. 1, no. 117 , p. , 2015. 
[13] J. P. Mendoza, J. L. Wielhouwer, and E. Kirchler, "The Backfiring Effect of Auditing on Tax," Compliance. J. Econ. Psychol., vol. 284, p. 294, 2017.

[14] J. Andreoni, B. Erard, and J. Feinstein, "No Title," Tax Compliance. J. Econ. Lit., vol. 36, no. 2, p., 1998.

[15] M. Ekananda, Analisis Ekonometrika Data Panel, 2nd ed. Jakarta: Mitra Wacana Media, 2016.

[16] M. W. Supriyadi, "No Title." 2017.

\section{APPENDIX}

Appendix A. Table of regional dummy classification.

\begin{tabular}{|l|l|l|}
\hline Number & \multicolumn{1}{|c|}{ Dummy's name } & \multicolumn{1}{c|}{ Regional Member (province) } \\
\hline 1. & Regional 0 /baseline & DKI Jakarta. \\
\hline 2. & Regional 1 & Province in Java Islands except DKI Jakarta \\
\hline 3. & Regional 2 & $\begin{array}{l}\text { Province in Sumatera, Riau Islands and Bangka } \\
\text { Belitung Islands }\end{array}$ \\
\hline 4. & Regional 3 & Province in Borneo Island \\
\hline 5. & Regional 4 & Province in Sulawesi Island \\
\hline 6. & Regional 5 & Province in Bali Island and Nusa Tenggara \\
\hline 7. & Regional 6 & Province in Maluku Islands and Papua \\
\hline
\end{tabular}

